\title{
Propellant Readiness Level: A Methodological Approach to Propellant Characterization
}

John A. Bossard, President, BSRD LLC, 11014 Blackbird Drive, Huntsville, AL, 35803. Associate Fellow AIAA.

Noah O. Rhys, President, Yetispace, Inc., 3701 Lakewood Drive, Huntsville, AL, 35811. Member AIAA.

\begin{abstract}
A methodological approach to defining propellant characterization is presented. The method is based on the well-established Technology Readiness Level nomenclature. This approach establishes the Propellant Readiness Level as a metric for ascertaining the readiness of a propellant or a propellant combination by evaluating the following set of propellant characteristics: thermodynamic data, toxicity, applications, combustion data, heat transfer data, material compatibility, analytical prediction modeling, injector/chamber geometry, pressurization, ignition, combustion stability, system storability, qualification testing, and flight capability. The methodology is meant to be applicable to all propellants or propellant combinations; liquid, solid, and gaseous propellants as well as monopropellants and propellant combinations are equally served. The functionality of the proposed approach is tested through the evaluation and comparison of an example set of hydrocarbon fuels.
\end{abstract}

\section{Introduction}

Various propellant options need to be considered during the research and development phases of any new space vehicle. Yet a systematic method for quantitatively determining and comparing the degree of understanding of a propellant does not currently exist. Rather, this determination is typically nonquantitative and based largely on the experience of the individuals conducting the studies. Even with sufficient knowledge, a quantitative comparison of readiness is generally not feasible without some sort of method to discriminate among the many attributes that characterize propellants.

Thus, a more objective evaluation methodology is needed to quantitatively measure candidate propellants so that relative and objective comparisons can be made. This methodology must also be simple enough to accommodate the wide variety of different attributes or characteristics of any particular propellant. In this paper, the authors present just such a method: the Propellant Readiness Level (PRL).

The PRL method is based on the Technology Readiness Level (TRL) scale first devised by J.C. Mankins in 1995 to objectively rank the development status of existing and emerging technology.[1] Both straightforward and generally applicable to a wide range of different technologies, the TRL scale has been extensively used since its introduction as a quantitative metric for comparative technology studies; it is now generally understood and familiar throughout the aerospace industry. Like the TRL, the PRL method quantifies a candidate propellant's readiness level in terms of major characteristics that have been suitably measured. 


\section{Defining the PRL Scale}

Mankins defined the TRL scale as nine levels of "readiness," or states of development, wherein TRL 1 is the lowest level of development and TRL 9 is the most developed.[1] Each level is defined in terms of the processes that would need to be completed for a particular technology to be usable. To be at a particular PRL, the propellant needs to have been characterized for all characteristics associated with that level. If, for example, a propellant has completed PRLs 1, 2, and 4, it would be considered to be at PRL 2.

The primary function of the PRL scale is to provide a logical framework for the quantitative assessment of propellant research and development. Without such a ranking system, statements about whether or not a propellant is well characterized can have only a qualitative meaning, and there is no quantitative way to judge which propellants are better characterized than others. Given these considerations, the PRLs are defined as follows.

\section{II.A PRL 1: Basic Properties}

At PRL 1, basic properties of the candidate propellant are measured using such criteria as molecular formula, density, melting and boiling points, heat of formation, latent heat of vaporization, viscosity, specific heat, ratio of specific heats, and thermal conductivity. The chemical formula and structure of the candidate propellant are also determined.

\section{II.B PRL 2: Potential Applications}

At PRL 2, possible applications for the candidate propellant are identified or invented. For example, the propellant may be used in a booster engine or tactical missile, or it may be stored in space. At this level, the proposed application is still speculative; the candidate propellant's conceived advantages have merely been extrapolated with respect to existing propellants. No experimental validation has occurred to support the propellant's suitability to the proposed application.

\section{II.C PRL 3: Lab-Based Testing}

At PRL 3, experimental efforts to evaluate the candidate propellant's suitability for proposed applications are initiated, perhaps by test firing the propellant in a small proof-of-concept apparatus. Measurements of the propellant's suitability as a regenerative coolant as it flows through a heated passage, such as a tube or channel, may also be measured and the passage examined for coking or reactivity.

\section{II.D PRL 4: Analytical Prediction Models}

At PRL 4, data from the testing can now anchor the analytic performance prediction models. Limited scalability of the results and models could reasonably be expected.

\section{II.E PRL 5: Thruster Testing}


At PRL 5, the candidate propellant is evaluated in a subscale apparatus that produces thrust. Analytic prediction models are updated to include the propellant's functional performance.

\section{II.F PRL 6: Subscale Breadboard Testing}

At PRL 6, the candidate propellant is evaluated under realistic test and environmental conditions in a subscale apparatus for all of its expected functions. The range of scalability of models is significantly increased to include predictions of the propellant's performance in full-scale hardware.

Successful demonstrations of all major functions that the propellant is expected to provide have been completed. Examples might include functionality for regenerative cooling, as a hydraulic fluid, as a pressurization source in a gas-generator configuration, and as turbomachinery working fluid.

\section{II.G PRL 7: Full-Scale Testing}

At PRL 7, the propellant has been evaluated in its full-scale intended propulsion device and its further characterization is dependent on the development of the design in which it is to be used. All expected functions of the propellant have been demonstrated in an integrated configuration. Expected environmental conditions can be simulated, but should reflect actual conditions as closely as possible.

\section{II.H PRL 8: Qualification Testing}

At PRL 8, the propellant has been evaluated in its full-scale intended application and has undergone testing and evaluation under all conditions that it is expected to encounter. PRL 8 is achieved when the propellant is operated in a TRL 8 propulsion device.

\section{II.I PRL 9: Flight Testing}

At PRL 9, the propellant has been successfully used in its intended application and is fully characterized.

\section{Characteristics of Propellants}

The term "propellant" as used herein can mean liquid, solid, or gaseous propellants, monopropellants, or combinations of fuels and oxidizers, as well as propellants that are chemically inert. Some characteristics are simply physical attributes, whereas more advanced characteristics describe the behavior of propellants when reacted. In these reacting cases, the propellant combination must be stated and the propellant characteristic refers to that particular combination. 
The following 14 attributes, which relate to the most important aspects of propellants considered for use in rocket propulsion systems, were selected to capture the necessary information needed for a quantitative assessment. It should be clearly understood that these do not necessarily represent the final list of possible characteristics. As new or additional characteristics are identified, they can be incorporated into the list and the proposed methodology reapplied.

\section{III.A Thermodynamic Data}

Thermodynamic data are associated with the physical and thermodynamic properties of the propellant and are typically needed to determine pressure, temperature, density, melting and boiling points, phase states, the enthalpy of formation, latent heat of vaporization, etc. For liquids and gases, this includes viscosity; for solids, this includes the material properties of compressive, tensile, and shear strength, as well as Poisson's ratio. Thermodynamic data are a property of a single propellant.

\section{III.B Toxicity}

Toxicity, which is a property of a single propellant, refers to the propensity of the propellant to cause physical injury through a poisoning process. This characteristic is not a measure of the toxicity of a propellant, but rather an indication of whether the toxicity of the propellant is known. For the vast majority of propellants under consideration, the toxicity is well characterized and usually listed on the Material Safety Data Sheet associated with that material.[2] However, new propellants for which toxicity may not have been established are constantly under development. In these cases, the lack of toxicity data represents a serious deficiency in the characterization of the propellant.

\section{III.C Applications}

The conceived or intended uses of a candidate propellant are its applications. Its basic thermodynamic data (described in Sec. III.A) will strongly indicate the most suitable applications by answering questions such as the following: Is the freezing point low? Is it a strong material? Does it have a large enthalpy of formation? The definition of a conceptual propulsion device that uses the propellant can also serve as an application.

\section{III.D Combustion Data}

Combustion data, which are propellant-combination specific, consist of information associated with the reaction of two or more propellants or between a catalyst and a monopropellant. Typical combustion parameters include the specific heat, molecular weight, enthalpy of formation, and temperature of the products of reaction as a function of mixture ratio. For a solid propellant, combustion data include burning rate constants for the burning rate equation used to model its combustion process. 


\section{III.E Heat Transfer Data}

Heat transfer characteristics are needed to model heat transfer between the candidate propellant and its environment. For a liquid, thermal conductivity and specific heat are important if the propellant is used to regeneratively cool a rocket chamber. The tendency for the propellant to decompose, crack, or coke is also important to know. For a solid, thermal conductivity is needed to understand and model the reaction and ablation processes in solid and hybrid rocket motors.

\section{III.F Material Compatibility}

Material compatibility data describe the interaction of the candidate propellant with surrounding materials. Propellant compatibility with metals, elastomers, and ceramics, as well as lubricants and sealants, is of typical interest. Sometimes combinations of multiple materials can catalyze a reaction that would not occur between only two materials.

\section{III.G Analytical Prediction Modeling}

Analytical prediction modeling enables the prediction of a candidate propellant's performance, which is essential to its development. The propellant can then be included in commonly used rocket propulsion analysis software, making it easily accessible to the modeling community.

\section{III.H Injector/Chamber Geometry}

The type of injector used to introduce liquid or gaseous propellants into the rocket chamber can have a significant influence on resulting rocket performance. The geometry of the chamber itself can also influence combustion behavior. The selection of injection and chamber schemes represents a high level of refinement and is often developed as an iteration of an initial configuration. Within the collective knowledge of rocket injector design, specific injector and chamber combinations have been found to work best for certain propellant combinations.

\section{III.I Pressurization}

Liquid and gaseous propellants require a pressurization system to push them into the rocket chamber. For pressure-fed systems, tank pressures can range from tens to hundreds of atmospheres. Yet even pump-fed systems typically require a tank pressurization system to keep pump-inlet conditions at a specified level. Some of the pressurant gas dissolves into the liquid propellant when liquids are pressurized. The amount that dissolves is a function of the pressurant gas, the liquid propellant, and the temperature and pressure at which the pressurization system is operated. Thus, gas saturation behavior makes up most of what is meant here by pressurization, although 
additional aspects of the pressurization characteristic could include the propellant's permeability into other materials found in a propulsion system.

\section{III.J Ignition}

Ignition describes the ease or difficulty of initiating the combustion process. It can be considered characterized when sufficient data and documented experience exist such that high ignition reliability is a reasonable expectation. High ignition reliability is quantified as the percentage of successful ignition events for the total number of ignition attempts. Fundamental thermochemical data can be associated with this characteristic, such as the minimum ignition energy required to initiate the basic reaction; however, the ignition reliability of a particular propellant with a particular injector/chamber geometry is often simply a practical matter of adjusting the ignition location to maximize ignition reliability.

\section{III.K Combustion Stability}

Combustion instabilities in rocket motors result from a number of different physical processes, all with a variety of different time constants; they are undesirable because they can reduce the delivered performance of a rocket or result in the dynamic disassembly of a rocket chamber. Very immature rocket motor concepts give little attention to combustion instabilities unless they are destructive, because a stable operating point can usually be found at which rocket performance can be assessed. As a particular rocket system matures, and attempts are made to upgrade and optimize its performance, combustion instabilities become more of an issue. For a candidate propellant to be considered characterized for combustion stability, it should have considerable test data associated with the measurement of combustion chamber pressures at sampling rates that are high enough for the combustion instabilities to be discerned. It should also involve hot-fire testing in which a deliberate perturbation is introduced into the chamber to see how the rocket motor responds; this is known as a "bomb test" and often employs an explosive squib fired during rocket motor operation. High-frequency pressure data collected during such a test constitute the proper combustion stability characterization of a particular propellant.

\section{III.L System Storability}

All propellants must be stored for some length of time before their use; this storage period can range from hours to years. Thus, system storability refers not only to long-term storage with regard to materials, but also to how well a candidate propellant can be kept in a ready-to-use state. Relevant concerns may include whether or not the performance of the propellant in its intended application degrades significantly over time and whether the propellant forms toxic or unstable compounds, either by itself or by reacting with container materials.

\section{III.M Qualification Testing}


Qualification testing refers to a comprehensive series of evaluations of a candidate propellant and its associated application to ensure proper function. These evaluations, typified by shock, vibration, and exposure to ionizing radiation, are quite specific and emerge from the anticipated conditions that the propellant and system will encounter when used.

\section{III.N Flight Capability}

The flight capability of a candidate propellant results from a long process of development, starting with the determination of the previous characteristics; by this point, only a relatively small handful of propellants will have been developed sufficiently for use in a flight test. Thus, a propellant is fully characterized only when it is used successfully to produce thrust for an air- or spacecraft. That is, the propellant has fulfilled its function and was not a source of failure for the flight vehicle.

\section{Associating Propellant Characteristics with the PRLs}

Using this proposed propellant characterization methodology, each propellant characteristic is assigned to a PRL. For some PRLs, there may be more than one characteristic assigned. As all possible characteristics have not yet been identified, any new or additional ones will need to be associated with a particular PRL. However, to make the PRL methodology meaningful, the same set of characteristics needs to be evaluated for the propellants under consideration.

The mapping of the given characteristics to particular PRLs is summarized in Table 1. As shown, if a propellant has available thermodynamic and toxicity data, identified applications, and combustion heat transfer and material compatibility measurements, it would be at PRL 3, or "characterized to PRL 3." A different propellant with all the previous data, but also entered into analytical modeling databases, would be at PRL 4. Note that without geometry effects and ignition data the propellant would not reach PRL 5. This process can be repeated for an individual propellant or a group of propellants to establish a self-consistent set of PRLs, with one PRL associated with each propellant.

\section{IV.A Example 1: Characterization of RP-1}

As an example of the proposed characterization methodology, the PRL of RP-1, a well-known and widely used hydrocarbon rocket propellant, is presented. For each propellant characteristic, an assessment is made to determine if there are sufficient data and/or documentation available to consider it understood. There is a subjective element to the assessment process; however, the more important aspect of this assessment is that it is consistent. This step requires the consultation of the available technical literature to see what specific data exist and what measurements have been made for that particular propellant and/or propellant combination. In practice, this represents the most laborintensive task in the characterization methodology. Going characteristic by characteristic, 
RP-1 is evaluated as to the adequacy of the available data concerning each characteristic. The results for RP-1, based on literature searches, yielded the assessment summarized in Table 2.

In Table 2, each number represents a citation of the reference containing the relevant information. When six or more references are found, the term "extensive" is used, indicating that the evaluation requirement has been more than satisfied. These results show that there are sufficient available data on RP-1 for each of the characteristics to be adequately understood. Using the proposed methodology, RP-1 is determined to be at PRL 9, because all characteristics up through PRL 9 are sufficiently represented with reference data and/or documentation. These results are consistent with the authors' expectation of the PRL of RP-1.

\section{IV.B Example 2: Characterization of Selected Hydrocarbon Fuels}

The evaluation of a family of hydrocarbon fuels reacted with liquid oxygen (LO2) to determine the PRLs of each fuel is presented. Some of these fuels have been considered as candidate propellants for proposed rocket systems. They range from widely used fuels, such as RP-1, to more developmental ones, such as methane, to research-level ones, such as the middle hydrocarbons.

Again, each of the 14 characteristics is assessed for each propellant to determine if there are sufficient data and/or documentation available. The results for these hydrocarbon fuels based on literature searches are presented in Table 3.

The results shown in Table 3 indicate that some propellants, such as methane, are well characterized across the board. Others, such as ethane and heptane, are not. As before, each number is a citation of the corresponding reference, whereas the term extensive indicates that the evaluation requirement has been more than satisfied. The PRL level for these hydrocarbons is shown in Table 4.

Table 4 illustrates that the proposed methodology has provided quantified results that could not have been extracted from intuition alone because of the vast amount of data and documentation that had to be examined. Here, we can see that methane is characterized to PRL 9, whereas ethane is characterized only to PRL 3. Before this analysis, it would have been difficult to state whether butane or ethane is better characterized, or more specifically, which has the higher PRL. The methodology presented here provides the quantified answer, backed up by an extensive reference list, that butane has a higher PRL than ethane and is therefore better characterized.

The value of this distinction is more than just academic. It is useful when conducting a trade study in which each of these propellants is under consideration, as quantitative evaluations can be made between them. Additionally, the direction of research and development can be guided. 


\section{Conclusions}

The PRL characterization methodology, based on Mankins's TRL[1], has been shown to provide a quantitative assessment of how well characterized a particular propellant might be; it can be applied to liquid, solid, and gaseous propellants, to monopropellants, and to both fuels and oxidizers. The resultant PRL that is generated for a propellant can serve as a basis for comparison in feasibility and trade study evaluations. It can also be used as a way to direct research priorities related to propellant research and development by readily indentifying propellants that need further development.

The proposed methodology was used to evaluate a set of hydrocarbon fuels, specifically methane, ethane, propane, butane, pentane, heptane, and RP-1. The PRL for each of these propellants was determined, presented, and shown to be consistent with a qualitative expectation as to how well characterized these propellants might be. High PRLs were shown for RP-1 and methane. Low PRLs were shown for several of the lessfamiliar hydrocarbon propellants, namely, ethane, butane, pentane, and heptane. This facilitated a relative ranking among these propellants, a task that would have been difficult or impossible without some sort of characterization methodology.

The authors strongly believe that this propellant characterization methodology will be useful to propellant developers, trade and feasibility analysts, and technical managers as a means of comparing the characterization of propellants and of prioritizing propellant research and development priorities.

\section{Acknowledgment}

The authors acknowledge Robert Garcia, NASA Propulsion Technical Fellow, and the NASA Engineering Safety Center for supporting the development of the PRL methodology and publishing our findings.

\section{References}

1. Mankins, J. C., "Technology Readiness Levels, A White Paper,” NASA Advanced Concepts Office, 6 April 1995.

2. Material Safety Data Sheets

3. NIST Refrop Database, Ver. 8.0, April 2007.

4. Masters, A. I., "Applicability of FLOX-Light Hydrocarbon Combinations as Liquid Rocket Propellants," AIAA Paper 65-581, 1965.

5. Masters, A. I., "Rocket Testing of Four FLOX-Light Hydrocarbon Propellant Combinations," AIAA Paper 66-624, 1966. 
6. Westerbrook , C. K., "Chemical Kinetic Modeling of Higher Hydrocarbon Fuels," AIAA Journal, Vol. 24, No. 12, pp. 2002-2009, 1986.

7. Rapp, D. C., "High Energy-Density Liquid Rocket Fuel Performance," NASA CR-185279; also AIAA Paper 90-1968, 1990.

8. Schneider, S. J., "On-Board Propulsion System Analysis of High Density Propellants," AIAA Paper 98-3670, 1998.

9. Gibbon, D., Paul, M., Smith, P., and McLellan, R., "The Use of Liquefied Gases in Small Satellite Propulsion Systems,” AIAA Paper 2001-3246, 2001.

10. Cohn, R.K., Danczyk, S. A., and Bates, R. W., "A Comparison of the Performance of Hydrocarbon Fuels in a Uni-Element Combustor," AIAA Paper 2003-4752, 2003.

11. Palaszewski , B., "NASA Advanced Fuels Program," Proceedings of the Seventh International Space University Alumni Conference, 1998.

12. Michel , R. W., "Combustion Performance and Heat Transfer Characterization of LOX/Hydrocarbon Type Propellants," NASA Contractor Report Number NASACR-171712, Aerojet, Sept. 1983.

13. Gross, R. S., "Combustion Performance and Heat Transfer Characterization of LOX/Hydrocarbon Type Propellants,” NASA CR-160874, Aug. 1980.

14. Roback, R., Szetela, E.J., and Spadaccini, L.J., "Deposit Formation in Hydrocarbon Rocket Fuels - Executive Summary Report," NASA CR-165492, Sept.1981.

15. Judd, D. C., "Photographic Combustion Characterization of LOX/Hydrocarbon Type Propellants," NASA CR-160906, Aug. 1980.

16. Allen, H. C., Technical Status Report RK-TPR-65-3, US Army Missile Command. Jan. 1965.

17. Laffitte, P., and Delbourgo, R., "Ignition by Condenser Sparks, Regions of Flammability of Ethane, Propane, N-Butane, and N-Pentane," Fourth International Symposium on Combustion, pp. 114-120, Sept. 1952; Abstract 1953-8005J.

18. Kraus, G., "Solid Rocket Nozzle Cooling," 16th JANNAF Meeting, Vol. II, pp. 249-286, June 1960; Abstract 1960-5263N.

19. Urban, D. L., Huey, S. P. C., and Dryer, F. L., "Evaluation of the Coke Formation Potential of Residual Fuel Oils," 24th International Symposium on Combustion, pp. 1357-1364, July 1992; Abstract 1999-2278EW. 
20. Hughes, R., and Simmons, F. F., "The Low-Temperature Combustion of NPentane," 12th International Symposium on Combustion, pp. 449-461, July 1968; Abstract 1968-5008AP.

21. Collins, J., Hurlbert, E., Romig, K., Melcher, J., Hobson, A., and Eaton, P., "SeaLevel Flight Demonstration and Altitude Characterization of a LO2/LCH4 Based Ascent Propulsion Lander," AIAA Paper 2009-4948, Aug. 2009.

22. Wilson, J. N., "High Energy Hydrocarbon Booster Fuels," Rept. S-14014, NASA CR-72438, Shell Development Company. Sept. 1968.

23. Stone, R., Tiliakos, N., Balepin, V., Tsai, C., and Engers, R., "Altitude Testing of LOX-Methane Rocket Engines at ATK GASL," AIAA Paper 2008-3701, June 2008.

24. Powell, O. A., Miller, J. E., Dreyer, C., and Papas, P., "Characterization of Hydrocarbon/Nitrous Oxide Propellant Combinations," AIAA Paper 2008-999, Jan. 2008.

25. Imbert, B., Catoire, L., Chaumeix, N., and Paillard, C., "Ignition Delays of Heptane/O2/Ar Mixtures in the 1300-1600K Temperature Range," Journal of Propulsion and Power, Vol. 20, No. 3, pp. 415-426, May-June 2004.

26. Babb, M., Gollahalli, S. R., and Sliepcevich, C. M., "Extinguishment of Liquid Heptane and Gaseous Propane Diffusion Flames," Journal of Propulsion and Power, Vol. 15, No. 2, , pp. 260-265, March-April 1999.

27. Priem, R. J., and Heidmann, M. F., "Vaporization of Propellants in Rocket Engines," ARS Journal, Vol. 29, No. 11, pp. 836-842, 1959.

28. Nayagam, V., Haggard, J. B., Jr., Colantonio, R. O., Marchese, A. J., Dryer, F. L., Zhang, B. L., and Williams, F. A., "Microgravity n-Heptane Droplet Combustion in Oxygen-Helium Mixtures at Atmospheric Pressure," AIAA Journal, Vol. 36, No. 8, pp. 1369-1378, Aug. 1998.

29. Horning, D. C., Davidson, D. F., and Hanson, R. K., "Study of the HighTemperature Auto-Ignition of n-Alkane/O2/Ar Mixtures," Journal of Propulsion and Power, Vol. 18, No. 2, pp. 363-371, March-April 2002.

30. Choi, M. Y., Dryer, F. L., Card, J. M., Williams, F. A., Haggard, J. B., Jr., and Borowski, B. A., "Microgravity Combustion of Isolated n-Decane and n-Heptane Droplets," AIAA Paper 1992-242, Jan. 1992.

31. Rosenberg, S. D., and Gage, M. L., "Compatibility of Hydrocarbon Fuels with Booster Engine Combustion Chamber Liners," Journal of Propulsion and Power, Vol. 7, No. 6, pp. 922-928, 1991. 
32. Liang, K., Yang, B., and Zhang, Z., "Investigation of Heat Transfer and Coking Characteristics of Hydrocarbon Fuels," Journal of Propulsion and Power, Vol. 14, No. 5, pp. 789-796, Sept.-Oct. 1998.

33. Mitchell, J. P., and Kaminski, W. R., "Space Storable Regenerative Cooling Investigation,” AIAA Paper 1968-616, June 1968.

34. Lamnaouer, M., Zinner, C., Rotavera, B., Petersen, E., and Bourque, G., "Butane Oxidation at Elevated Temperatures," AIAA Paper 2007-5658, June 2007.

35. Gibbon, D. M., Baker, A. M., Nicolini, D., Robertson, D., and Dye, C., "The Design, Development, and In-Flight Performance of a Low Power Resistojet Thruster," AIAA Paper 2003-4548, July 2003.

36. Cohn, R. K., Strakey, P. A., Bates, R. W., Talley, D. G., Muss, J. A., and Johnson, C. W., "Swirl Coaxial Injector Development," AIAA Paper 2003-125, Jan. 2003.

37. Starikovskaia, S. M., Anikin, N. B., Kosarev, I. N., Popov, N. A., and Starikovskii, A., "Analysis of Ignition by Nonequilibrium Sources. Ignition of Homological Series of Hydrocarbons by Volume Nanosecond Discharge," AIAA Paper 2006-616, Jan. 2006.

38. Babushok, V. I., and Tsang, W., "Kinetic Modeling of Heptane Combustion and PAH Formation," Journal of Propulsion and Power, Vol. 20, No. 3, pp. 403-414, May-June 2004.

39. Wickham, D. T., Engel, J. R., Hitch, B. D. and Karpuk, M. E., "Initiators for Endothermic Fuels," Journal of Propulsion and Power, Vol. 17, No. 6, pp. 1253 1257, Nov.-Dec. 2001.

40. Shuen, J. S., and Yang, V., "Combustion of Liquid Fuel Droplets in Supercritical Conditions," AIAA Paper 1991-78, Jan. 1991.

41. Bryant, J. T., and Wood, S. E., "Liquid Bipropellant Ignition and Combustion in an Instrumented Drop-Weight Tester," AIAA Journal, Vol. 13, No. 10, pp. 1410$1411,1975$.

42. Lee, K., Seo, S., Song, J., Han, Y., Choi, H., and Seol, W., "Combustion Stability Assessment of Double Swirl Coaxial Injectors Using Simulant Propellants," AIAA Paper 2005-4443, July 2005.

43. Muss, J. A., and Pieper, J. L., "Performance and Stability Characterization of LOX/Hydrocarbon Injectors,” AIAA Paper 1988-3133, July 1988.

44. Tiliakos, N., Tyll, J. S., Herdy, R., Sharp, D., Moser, M., and Smith, N., "Development and Testing of a Nitrous Oxide/Propane Rocket Engine," AIAA paper 2001-3258, July 2001. 
45. Eisenber, J. D., and Chambellan, R. E., "Tankage Systems for A Methane Fueled Supersonic Transport," AIAA Paper 1968-196, Feb. 1968.

46. Williams, A. F., and Lom, W. L., "Liquefied Petroleum Gases: A Guide to Properties, Applications and Usage of Propane and Butane," Wiley, Hoboken, NJ, 1974; ISBN 853120064.

47. Goodger, E. M., "Hydrocarbon Fuels: Production, Properties, and Performance of Liquids and Gases,” Wiley, Hoboken, NJ, 1975; ISBN 0 470-31365-x.

48. Aul, C. J., Petersen, E. L., Walker, B. C., and Curran, H. J., "Ignition of Methane and Ethane Blends with Oxygen at Engine Conditions," AIAA Paper 2008-4768, July 2008.

49. Edwards, T., and Maurice, L., "HyTech Fuels/Fuel System Research," AIAA 1998-1562, April 1998. 
Table 1. Assignment of characteristics to particular PRLs

\begin{tabular}{|c|c|c|c|c|c|c|c|c|c|c|c|c|c|c|}
\hline \multirow[b]{2}{*}{ PRL } & \multicolumn{2}{|c|}{ PRL1 } & \multirow{2}{*}{$\begin{array}{c}\text { PRL2 } \\
\text { Applications }\end{array}$} & \multirow[b]{2}{*}{ Combustion Data } & \multicolumn{2}{|l|}{ PRL3 } & \multirow{2}{*}{$\begin{array}{c}\text { PRL4 } \\
\begin{array}{c}\text { Analytical } \\
\text { Predictions }\end{array} \\
\end{array}$} & \multicolumn{2}{|c|}{ PRL5 } & \multicolumn{2}{|c|}{ PRL6 } & \multirow{2}{*}{\begin{tabular}{c|} 
PRL7 \\
system storability \\
\end{tabular}} & \multirow{2}{*}{$\begin{array}{c}\text { PRL } 8 \\
\text { Qualification } \\
\text { Testing } \\
\end{array}$} & \multirow[b]{2}{*}{ flight Test } \\
\hline & $\begin{array}{c}\text { Thermo-dynamic } \\
\text { Data }\end{array}$ & Toxicity & & & $\begin{array}{l}\text { Heat Transfer } \\
\text { Char. }\end{array}$ & Materials Compat. & & \begin{tabular}{|c|} 
Injector/ Chamber \\
geometry
\end{tabular} & Ignition & Pressurization & $\begin{array}{c}\text { Combustion } \\
\text { Stability Datata }\end{array}$ & & & \\
\hline 1 & $x$ & $x$ & & & & & & & & & & & & \\
\hline 2 & & & $x$ & & & & & & & & & & & \\
\hline 3 & & & & $x$ & $x$ & $x$ & & & & & & & & \\
\hline 4 & & & & & & & $x$ & & & & & & & \\
\hline 5 & & & & & & & & $x$ & $x$ & & & & & \\
\hline 6 & & & & & & & & & & $x$ & $x$ & & & \\
\hline 7 & & & & & & & & & & & & $x$ & & \\
\hline 8 & & & & & & & & & & & & & $\underline{x}$ & \\
\hline 9 & & & & & & & & & & & & & & $x$ \\
\hline
\end{tabular}

Table 2. Characteristics evaluation results for RP-1

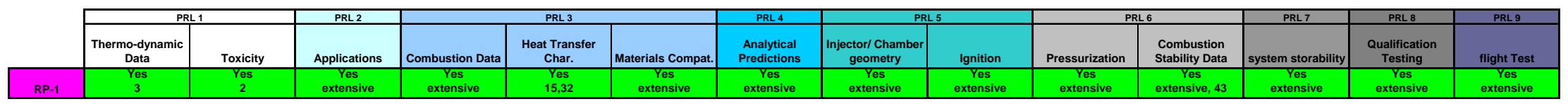

Table 3. Characteristics evaluation results for the hydrocarbon fuels

\begin{tabular}{|c|c|c|c|c|c|c|c|c|c|c|c|c|c|c|}
\hline & \multicolumn{2}{|c|}{ PRL1 } & \multirow{2}{*}{$\begin{array}{c}\text { PRL 2 } \\
\text { Applications }\end{array}$} & \multicolumn{3}{|c|}{ PRL3 } & \multirow{2}{*}{$\begin{array}{c}\text { PRL 4 } \\
\text { Analytical } \\
\text { Predictions }\end{array}$} & \multicolumn{2}{|c|}{ PRL5 } & \multicolumn{2}{|c|}{ PRL 6} & \multirow{2}{*}{\begin{tabular}{|c|} 
PRL7 \\
system storability \\
\end{tabular}} & \multirow{2}{*}{$\begin{array}{c}\text { PRL } 8 \\
\text { Qualification } \\
\text { Testing }\end{array}$} & \multirow{2}{*}{$\begin{array}{l}\text { PRL9 } \\
\text { flight Test }\end{array}$} \\
\hline & $\begin{array}{c}\text { Thermo-dynamic } \\
\text { Data }\end{array}$ & Toxicity & & Combustion Data & $\begin{array}{l}\text { Heat Transfer } \\
\text { Char. }\end{array}$ & Materials Compat. & & \begin{tabular}{|l|} 
Injector/ Chamber \\
geometry
\end{tabular} & Ignition & Pressurization & $\begin{array}{c}\text { Combustion } \\
\text { Stability Data }\end{array}$ & & & \\
\hline methane & $\begin{array}{c}\text { Yes } \\
3\end{array}$ & $\begin{array}{c}\text { Yes } \\
2\end{array}$ & $\begin{array}{c}\text { Yes } \\
5,7,23,24,47\end{array}$ & $\begin{array}{c}\text { Yes } \\
5,7,23,24,48\end{array}$ & $\begin{array}{c}\text { Yes } \\
4,5,15,32,33\end{array}$ & \begin{tabular}{c|} 
Yes \\
31
\end{tabular} & $\begin{array}{c}\text { Yes } \\
5,7,23,24,48\end{array}$ & $\begin{array}{c}\text { Yes } \\
5,15,23\end{array}$ & $\begin{array}{c}\text { Yes } \\
4,6,37,47,48\end{array}$ & $\begin{array}{l}\text { Yes } \\
45\end{array}$ & $\begin{array}{c}\text { Yes } \\
42,43\end{array}$ & $\begin{array}{c}\text { Yes } \\
\text { extensive }\end{array}$ & $\begin{array}{c}\text { Yes } \\
\text { extensive }\end{array}$ & $\begin{array}{l}\text { Yes } \\
21\end{array}$ \\
\hline ethane & $\begin{array}{c}\text { Yes } \\
3 \\
\end{array}$ & $\begin{array}{c}\text { Yes } \\
2 \\
\end{array}$ & $\begin{array}{c}\text { Yes } \\
\text { Yes, } \\
24,47 \\
\end{array}$ & 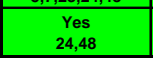 & $\begin{array}{c}\text { Yes } \\
4,33 \\
\end{array}$ & $\begin{array}{r}\text { Yes } \\
31,49 \\
\end{array}$ & 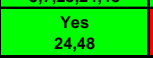 & No & 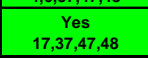 & No & No & No & № & No \\
\hline propane & $\begin{array}{l}\text { Yes } \\
3 \\
\end{array}$ & $\begin{array}{l}\text { Yes } \\
2 \\
\end{array}$ & $\begin{array}{c}\text { Yes } \\
5,7,12,24,26,45 \\
\end{array}$ & $\begin{array}{c}\text { Yes } \\
5,7,72,24,26,46 \\
\end{array}$ & \begin{tabular}{|c|} 
Yes \\
$4,5,12,13,14,15,32$ \\
\end{tabular} & $\begin{array}{c}\text { Yes } \\
12,13,31,46 \\
\end{array}$ & $\begin{array}{c}\text { Yes } \\
5,7,12,24,26,46 \\
\end{array}$ & $\begin{array}{c}\text { Yes } \\
5,12,13,14,15 \\
\end{array}$ & $\begin{array}{c}\text { Yes } \\
4,6,17,29,37,47 \\
\end{array}$ & $\begin{array}{l}\text { Yes } \\
44,46 \\
\end{array}$ & $\begin{array}{c}\text { Yes } \\
12,42,43\end{array}$ & No & No & $\begin{array}{c}\text { Yes } \\
9 \\
9\end{array}$ \\
\hline butane & $\begin{array}{l}\text { Yes } \\
3 \\
\end{array}$ & $\begin{array}{l}\text { Yes } \\
2 \\
\end{array}$ & $\begin{array}{c}\text { Yes } \\
10,34,45 \\
\end{array}$ & $\begin{array}{c}\text { Yes } \\
10,34,46 \\
\end{array}$ & \begin{tabular}{|c|} 
Yes \\
$4,16,18,19,35$ \\
\end{tabular} & $\begin{array}{c}\text { Yes } \\
46\end{array}$ & $\begin{array}{c}\text { Yes } \\
10,34,46 \\
\end{array}$ & $\begin{array}{c}\text { Yes } \\
36 \\
\end{array}$ & $\begin{array}{c}\text { Yes } \\
6,17,29,34,37,47 \\
\end{array}$ & $\begin{array}{l}\text { Yes } \\
46 \\
\end{array}$ & № & No & No & $\begin{array}{l}\text { Yes } \\
9,35\end{array}$ \\
\hline pentane & $\begin{array}{c}\text { Yes } \\
3 \\
\end{array}$ & $\begin{array}{c}\text { Yes } \\
2 \\
\end{array}$ & $\begin{array}{c}\text { Yes } \\
4,5,8,20,22,40\end{array}$ & $\begin{array}{c}\text { Yes } \\
4,5,8,20,22,40,41 \\
\end{array}$ & $\begin{array}{c}\text { Yes } \\
4,5,19 \\
\end{array}$ & $\begin{array}{l}\text { Yes } \\
41 \\
\end{array}$ & $\begin{array}{c}\text { Yes } \\
4,5,8,20,22,40,41 \\
\end{array}$ & $\begin{array}{c}\text { Yes } \\
5 \\
\end{array}$ & $\begin{array}{c}\text { Yes } \\
4,17,37,41 \\
\end{array}$ & No & No & № & No & No \\
\hline heptane & $\begin{array}{c}\text { Yes } \\
3\end{array}$ & $\begin{array}{c}\text { Yes } \\
2\end{array}$ & \begin{tabular}{|c|} 
Yes \\
$25,26,27,28,30,37$
\end{tabular} & \begin{tabular}{|c|} 
Yes \\
$25,26,27,28,30,38$ \\
\end{tabular} & $\begin{array}{l}\text { Yes } \\
39\end{array}$ & $\begin{array}{l}\text { Yes } \\
41 \\
\end{array}$ & \begin{tabular}{|c|} 
Yes \\
$25,26,27,28,30,38$ \\
\end{tabular} & $\begin{array}{c}\text { Yes } \\
27 \\
\end{array}$ & $\begin{array}{c}\text { Yes } \\
25,29,37,41 \\
\end{array}$ & No & No & No & No & No \\
\hline RP-1 & $\begin{array}{c}\text { Yes } \\
3\end{array}$ & $\begin{array}{c}\text { Yes } \\
2\end{array}$ & $\begin{array}{c}\text { Yes } \\
\text { extensive }\end{array}$ & $\begin{array}{c}\text { Yes } \\
\text { extensive }\end{array}$ & $\begin{array}{c}\text { Yes } \\
15,32\end{array}$ & $\begin{array}{c}\text { Yes } \\
\text { extensive }\end{array}$ & $\begin{array}{c}\text { Yes } \\
\text { extensive }\end{array}$ & $\begin{array}{c}\text { Yes } \\
\text { extensive }\end{array}$ & $\begin{array}{c}\text { Yes } \\
\text { extensive }\end{array}$ & $\begin{array}{c}\text { Yes } \\
\text { extensive }\end{array}$ & $\begin{array}{c}\text { Yes } \\
\text { extensive, } 43\end{array}$ & $\begin{array}{c}\begin{array}{c}\text { Yes } \\
\text { extensive }\end{array} \\
\text {. }\end{array}$ & $\begin{array}{c}\text { Yes } \\
\text { extensive }\end{array}$ & $\begin{array}{c}\begin{array}{c}\text { Yes } \\
\text { extensive }\end{array} \\
\text {. }\end{array}$ \\
\hline
\end{tabular}


Table 4. PRL summary for selected hydrocarbon fuels with LO2

\begin{tabular}{|c|c|}
\cline { 2 - 2 } \multicolumn{1}{c|}{} & PRL \\
\hline methane & 9 \\
\hline ethane & 4 \\
\hline propane & 6 \\
\hline butane & 5 \\
\hline pentane & 5 \\
\hline heptane & 5 \\
\hline RP-1 & 9 \\
\hline
\end{tabular}

